\title{
Proceedings of the Society for Experimental Biology and Medicine
}

\section{Mechanisms of Antineoplastic Action of Somatostatin Analogs}

Michael N. Pollak and Andrew V. Schally

Proc Soc Exp Biol Med 1998, 217:143-152.

doi: 10.3181/00379727-217-44216

Updated information and services can be found at: http://ebm.rsmjournals.com/content/217/2/143

21 online articles that cite this articles can be accessed at: http://ebm.rsmjournals.com/content/217/2/143\#otherarticles

(C) 2008 Society for Experimental Biology and Medicine 


\title{
Mechanisms of Antineoplastic Action of Somatostatin Analogs (44216)
}

\author{
Michael N. PollaK, ${ }^{*}, 1$ AND ANDREW V. Schally $\dagger$ \\ Departments of Medicine and Oncology, * Lady Davis Research Institute, McGill University, Montreal, Quebec, Canada H3T 1E2; \\ Endocrine, Polypeptide and Cancer Institute, V.A. Medical Center and Department of Medicine, $\dagger$ Tulane University School of
} Medicine, New Orleans, Louisiana 70146

\begin{abstract}
Over the past decade, impressive antineoplastic activity of somatostatin analogs has been demonstrated in many tumor models. More recent research has provided information regarding mechanisms underlying the antiproliferative and apoptosis-inducing actions of these compounds. These include both 'direct' mechanisms that are sequellae of binding of somatostatin analogs to somatostatin receptors present on neoplastic cells and 'indirect' mechanisms related to effects of somatostatin analogs on the host. The upregulation of intracellular tyrosine phosphatase activity triggered by binding of ligands to the type II somatostatin receptor has received considerable attention as a direct mechanism, not only because this activity is the converse of the tyrosine kinase activity associated with many peptide mitogen receptors, but also because the type II somatostatin receptor is frequently expressed by common human neoplasms, including breast cancer. The potential importance of indirect mechanisms of action of somatostatin analogs, such as alterations in host insulin-like growth factor physiology, is emphasized by the in vivo antineoplastic activity of these compounds against somatostatin receptor-negative neoplasms. Clinical efficacy and a favorable toxicity profile of somatostatin analogs in the treatment of relatively uncommon conditions such as acromegaly and neuroendocrine tumors have already been demonstrated. Preclinical data now are sufficient to justify controlled clinical trials in breast, prostate, and pancreatic cancer. The development of monthly depot formulations will facilitate the clinical evaluation of somatostatin analogs for these and other indications.

[P.S.E.B.M. 1998, Vol 217]
\end{abstract}

\section{Background}

Development of Noncytotoxic Therapies for Cancer. Although cytotoxic chemotherapy is very effective in the management of certain neoplasms such as tes-

\footnotetext{
${ }^{1}$ To whom requests for reprints should be addressed at 3755 Cote St. Catherine Road, Montreal, Quebec, Canada H3T 1E2. E-mail: MD49@MUSICA.MCGILL.CA. Dr. Pollak's laboratory research is funded by the National Cancer Institute of Canada and he is supported by the Fonds de la Recherche en Santé du Québec and the Reisman Family Foundation as a Clinician Scientist at The Lady Davis Research Institute of McGill University. Dr. A. V. Schally is supported by the Medical Research Service of the Veteran Affairs Department.
}

$0037-9727 / 98 / 2172-0143 \$ 10.50 / 0$

Copyright $(\subset) 1998$ by the Society for Experimental Biology and Medicine ticular cancer, the efficacy of this therapeutic modality in the treatment of many common neoplasms such as those of the lung, breast, prostate, bowel, pancreas, and kidney is limited. "Cure" of macroscopic metastatic disease is exceedingly rare, and palliation of symptoms of metastatic neoplasms by chemotherapy can be problematic as the toxicity of the treatment often mitigates any improvement in quality of life resulting from the temporary decrease in tumor burden. Post-surgical adjuvant chemotherapy is frequently without beneficial effect (as in the case of renal cancer), or is associated with only small improvements in disease-free survival (for instance in the case of colon cancer). This situation has not only motivated attempts to develop novel cytotoxic agents, but also has stimulated 
research regarding innovative noncytotoxic approaches to cancer treatment (1-3).

Among various hormonal agents, increasing attention is being directed to somatostatin analogs (4-6). This is largely due to the demonstration of antineoplastic activity of these compounds in a variety of experimental models in vitro and in vivo (reviewed in Refs. 4-6). Further interest is due to the recent description of some aspects of the molecular mechanisms underlying this antineoplastic activity (7-19). Clinical experience with somatostatin analogs in the treatment of conditions such as acromegaly and carcinoid syndrome has shown that they are well tolerated compared to antineoplastic therapies currently in use (20). Therefore, there is much interest in carrying out controlled clinical trials in appropriate cohorts of patients to determine whether or not the encouraging results from preclinical research will translate into clinically useful antineoplastic activity.

In this article, we discuss recent concepts regarding the mechanisms of antineoplastic action of somatostatin analogs and summarize their status as drug candidates for treatment of non-neuroendocrine neoplastic diseases.

Somatostatin and the Development of Somatostatin Analogs. Somatostatin was originally isolated from ovine and subsequently porcine hypothalami as a substance that inhibited growth hormone $(\mathrm{GH})$ secretion by the pituitary gland (reviewed in Refs. 21, 22). It was subsequently recognized that somatostatin is widely expressed in many organs and that the regulation of $\mathrm{GH}$ release represents a specialized function of the somatostatin molecule that arose relatively late in evolution. Somatostatin-like immunoreactivity has since been described in vertebrates, invertebrates, plants, and even a protozoan $(21,23)$. This suggests the possibility that somatostatin-like molecules have served roles in intercellular communication since the evolution of multicellular organisms and that somatostatin plays an important role in regulating cellular proliferation.

The physiological effects of somatostatin are predominately inhibitory. Antiproliferative actions are seen in many cell types of higher organisms. Recent studies suggest these actions are correlated with induction of apoptosis in certain instances (8). Somatostatin also inhibits exocrine secretion in the digestive system, inhibits endocrine secretion of many hormones, modulates biliary and gastrointestinal motility, and has additional roles as a neurotransmitter (21). Expression of the gene encoding somatostatin is widespread in the central and peripheral nervous systems and also is found in neuroendocrine cells that are found in most organ systems. The physiological roles of these cells and the somatostatin they secrete in a paracrine manner in organs such as breast, prostate, and kidney remain incompletely understood. The development of somatostatin-gene and somatostatin-receptor-gene knock-out models is an experimental strategy that may be useful in further investigation of this issue.

Two molecular forms of somatostatin, SST-14 and SST-28, have been identified $(22,24)$. In mammals, these two peptides are encoded by a single gene that yields a peptide (preprosomatostatin) that is subsequently cleaved to generate SST-14 or SST-28. In lower vertebrates, separate genes encode SST-14 and SST-28 (25).

The development of synthetic analogs of somatostatin was necessary in view of the many actions of somatostatin and its short half-life (22). It was quickly recognized that naturally occurring somatostatin was difficult to use for therapeutic purposes because of its short serum half-life $(\sim 3$ min) (3). Furthermore, there was much interest in determining whether analogs could be designed to be more selective with respect to specific physiological effects, for example a preferential suppression of growth hormone release over inhibition of insulin secretion. Earlier work regarding structure-function relationships and the development of somatostatin analogs has been reviewed $(3,5,26)$. An important advance was the design of the analog octreotide (SMS 201995) by Bauer et al. in 1982 (27). This compound contains the sequence of amino acids 7-10 (Phe-Trp-Lys-Thr) of native somatostatin, which was previously identified as essential for biological activity by Veber et al. (28). Dtryptophan was used rather than the L-isomer to prolong the half-life of the compound, and a cyclic configuration was obtained by the addition of cysteine residues on either side of the active region and cross-linking these residues. Finally, D-phenylalanine was incorporated as an $\mathrm{N}$-terminal residue, and Thr-ol as a C-terminal amino alcohol. This compound was found to be approximately 50-times more potent than SST-14 in suppressing release of GH, but was weaker with respect to suppression of insulin and glucagon release. Many other analogs such as RC-160 were subsequently synthesized $(29,30)$ and screened for ability to suppress $\mathrm{GH}$ release or in some cases for antineoplastic activity. Most studies concerning potential applications in oncology were carried out using three analogs: octreotide, RC-160, and somatuline. However, it must be emphasized that while these analogs have more in vivo antineoplastic activity than many others examined to date, it has not been established that any of them represents an 'optimum' analog for clinical use in Oncology.

Recently, five somatostatin receptor subtypes, SSTR-1 to SSTR-5, have been cloned and functionally characterized $(12-16,18,19,31)$. They all bind somatostatin-14 and somatostatin-28 with similar affinity but show major differences in their affinities for various somatostatin analogs (12, $18,19)$. Octreotide has very low $\left(\mathrm{IC}_{50}>1000 \mathrm{n} M / \mathrm{l}\right)$ and $\mathrm{RC}-160$ has low $\left(\mathrm{IC}_{50}>150 \mathrm{nM} / \mathrm{l}\right)$ affinity for SSTR-1, but both have high binding affinity for somatostatin receptor subtype SSTR-2 (octreotide, $\mathrm{IC}_{50}=0.32 \mathrm{n} M / 1$; RC-160, $\mathrm{IC}_{50}=0.10 \mathrm{n} M / 1$ ) and can induce a stimulation of tyrosine phosphatase activity and an inhibition of the proliferation of cells expressing SSTR-2 $(12,18,19)$. This implicates tyrosine phosphatase as a transducer of the growth inhibition signal. RC-160 and octreotide also exhibit moderate to high affinities for SSTR-3 and SSTR-5 (12, 18). RC-160 has higher affinity for SSTR-4 than does octreotide (19). The 
phosphoinositide/calcium pathway rather than the phosphatase pathway is implicated in SSTR-5-mediated signal transduction $(12,18)$. Ongoing research regarding the roles of each of the five somatostatin receptor subtypes in mediating antineoplastic effects, together with data concerning the subtype-specific agonist activity of various analogs, may identify optimum compounds for specific applications in Oncology (32).

It is likely that an important determinant of the specificity of analogs in mimicking certain actions of somatostatin over others (e.g., preferential or selective growth hormone suppression over insulin suppression) relates to the different affinity of analogs for the somatostatin receptor subtypes and to the heterogeneity of somatostatin receptor profile of various cells that are targets for somatostatin action. Other factors, including the pharmacokinetics and tissue distribution of somatostatin analogs, may also play roles in this regard.

Expression of Somatostatin Receptors by Normal and Neoplastic Tissues. The first step in the mediation of all actions of somatostatin analogs, including antineoplastic actions, involves the binding of the analog to a somatostatin receptor. An antineoplastic action of a somatostatin analog is classified as 'direct' if it is a consequence of binding of the analog to somatostatin receptors present on neoplastic cells, or 'indirect' if it is a consequence of binding of the analog to somatostatin receptors present on normal cells of the host. For example, it has been proposed that the inhibitory effect of the somatostatin analog octreotide on a somatostatin receptor-negative, insulinlike growth factor I (IGF-I)-responsive experimental sarcoma is a consequence of suppression of the host GH-IGF-I axis following binding of octreotide to somatostatin receptors of pituitary somatotrophs (33).

Initial studies regarding somatostatin receptor distribution in normal tissues were based on competitive binding assays using radiolabeled somatostatin or somatostatin analogs, or on radioautographic techniques. Binding sites have been documented in many normal human tissues, including pituitary, brain, gut, pancreas, and lymphoid tissue (reviewed in Ref. 14). More recently, research has been undertaken to classify somatostatin binding sites with respect to receptor subtype. Such work is presently being done by hybridization of mRNA with receptor subtype-specific probes, but work is underway to develop antibodies that specifically detect each of the five known receptor subtypes at the protein level (15). Localization studies of somatostatin receptors on specific cell types within somatostatinreceptor positive tissues demonstrate heterogeneity of distribution. For example, in normal prostate, there is evidence that receptors are more abundant in microvessels than in glandular tissue $(34,35)$.

Earlier competitive binding and autoradiographic studies, demonstrating that neuroendocrine tumors such as pituitary adenomas, islet cell tumors, pheochromocytomas, and carcinoid tumors have abundant high-affinity somato- statin binding sites, have been confirmed by more recent gene expression data (for example see Ref. 36). The variable expression of mRNAs of somatostatin receptor subtypes by different pancreatic and colon cancer cell lines indicates the potential importance of a precise characterization of receptor subtypes in tumor tissue before therapy with somatostatin analogs if 'direct' antineoplastic effects are to be maximized $(12,18)$. A recent report by Buscail and collaborators (37) provides data that suggest that at least a significant subset of human pancreatic and colorectal cancers do not express SSTR-2, which is the main receptor subtype for somatostatin analogs RC-160 and octreotide. These data suggest that if clinical trials demonstrate antineoplastic activity for these cancers, the SSTR-2-related direct mechanisms would be less important than indirect mechanisms or direct mechanisms related to other somatostatin receptors. The well-characterized MIAPaCa human pancreatic cell line does express SSTR-2, indicating that somatostatin receptor profiles of commonly used laboratory models may imperfectly reflect receptor profiles present on primary human neoplastic tissue.

Tumors of the nervous system, including astrocytomas and neuroblastomas, have been shown to have somatostatin binding sites (38). This is not unexpected in view of the presence and known physiological roles of somatostatin receptors on the cells of origin of these tumors. However, somatostatin receptors have also been detected in cancers arising from tissues where the physiological function of somatostatin receptors is less clear, such as those of the breast (39) and prostate gland (34). In vitro studies of various cloned adenocarcinoma cell lines have shown that these neoplastic cells exhibit somatostatin receptors, although at a much lower level than neuroendocrine tumors (for example, see Ref. 40). While binding assays performed on nonneuroendocrine neoplastic tissue have demonstrated somatostatin binding sites, few studies to date have examined the proportion of these sites that are on the neoplastic cells themselves, as distinct from nontransformed stromal and vascular cells, or have defined the proportion of binding attributable to each receptor subtype.

More recent research has shown that more than $50 \%$ of breast cancers exhibit somatostatin binding sites. Their abundance is sufficient to allow for in vivo imaging of a large proportion of human breast cancers by means of radioscintigraphy following intravenous injection of indium ${ }^{111}$-labeled octreotide (41). Similar imaging techniques with ${ }^{111}$ In-DTPA-D-Phe ${ }^{1}$ octreotide have been used to demonstrate somatostatin receptors in various human neoplasms including lymphomas, neuroblastomas, and lung cancers $(42,43)$. In addition, metastases can be visualized by scintigraphy with radiolabeled octreotide (43). Scintigraphy may be of use in determining which tumors are likely to respond via a direct mechanism to treatment with somatostatin analogs. In many cases, a positive scintigram with

${ }^{111}$ In-DTPA-octreotide predicted a good response to treatment with octreotide (43). The dramatically effective use of 
somatostatin analogs in thymoma (44) provides separate evidence of the importance of scintigraphy: clinical use of octreotide for this indication was attempted on the basis of scintigraphic evidence of octreotide binding sites. If future studies demonstrate conclusively a relationship between intensity of signal obtained with somatostatin analog scintigraphy and response to therapy, it is possible that scintigraphy might enable selection of the best somatostatin analog to be used in the treatment of a specific cancer without the need for biopsy. ${ }^{111}$ In-DTPA-D-Phe ${ }^{1}$ RC-160 (45) and ${ }^{111}$ In-DTPA-D-Phe ${ }^{1}$ octreotide (43) have both been used in clinical studies, but individual human tumors have not been sequentially imaged in vivo with these compounds to investigate the significance of laboratory data that suggest that some human tumors including cancers of the breast, exocrine pancreas, prostate, and colon may bind RC-160 with higher affinity than octreotide $(3,12,18,45)$.

There is considerable heterogeneity between and within individual tumors with respect to density of somatostatin receptor binding sites. In addition, there is evidence to suggest that somatostatin receptors are preferentially expressed in more differentiated as compared to more anaplastic tumors. Glial tumors represent an example of this: somatostatin receptors are not present in glioblastoma multiforme, the most anaplastic glial tumor, whereas they are relatively abundant in gliomas (46). Breast cancer may represent another instance: there are data suggesting higher levels of somatostatin binding in tumors with more favorable prognosis than in less differentiated estrogen receptor-negative ones (47). This suggests the possibility that somatostatin receptors represent differentiation markers in certain neoplastic cell lineages. Furthermore, loss of expression of functional somatostatin receptors may be functionally implicated in the clinically important phenomenon of neoplastic progression. If one assumes that somatostatin receptors are components of physiological control systems that constrain proliferation, then the loss of functional receptors due to a somatic cell mutation or an epigenetic event within a single neoplastic cell would confer a proliferative advantage to that cell and its progeny. This would result in the emergence and dominance of the more rapidly proliferating somatostatin receptor negative clone, and contribute to the neoplastic progression of the neoplasm to a more aggressive, less differentiated phenotype. In this context, somatostatin receptors as well as related proteins involved in somatostatin signal transduction should be regarded as candidate tumor suppressor genes. A report of a mutated SSTR2 gene in human small-cell lung cancer is consistent with this view (48).

\section{Direct Mechanisms of Action}

There has been considerable recent progress in the characterization of high-affinity cell-surface somatostatin receptors. Specific binding sites for somatostatin were described in brain and pituitary tissue some 15 years ago (49). Heterogeneity of binding sites was observed soon thereafter
(50). More recent work has resulted in the cloning of five distinct somatostatin receptor molecules (reviewed in Refs. 14, 19, 31). Emerging information regarding signal transduction pathways linked to somatostatin receptors is key to understanding the mechanisms of action of somatostatin analogs. Transfection of each of the five cloned human somatostatin receptors into somatostatin-receptor-negative target cell lines has determined specific signal transduction pathways associated with individual somatostatin receptor subtypes.

It has recently been demonstrated that SSTR3 transfected CHO cells respond to nanomolar concentrations of octreotide by upregulation of $\mathrm{p} 53$ and subsequent induction of apoptosis (8). This work implies that the presence of a particular somatostatin receptor subtype on a neoplastic cell does not necessarily indicate that the relevant antiproliferative or apoptosis-inducing signal transduction pathway is intact. Octreotide would be predicted to be ineffective in inducing apoptosis via SSTR3 in the significant proportion of human cancers that have mutations in the p53 gene.

Most investigators now believe that all somatostatin receptors are negatively coupled to adenyl cyclase (although this may not be via the same pertussis-toxin-sensitive, GTPbinding proteins for all receptors in all cell types), leading to a decrease in intracellular cyclic AMP concentration following ligand binding. Another signal transduction pathway associated with SSTR2 links ligand binding to upregulation of phosphoprotein phosphatase activity $(9,12,18)$. SSTR2 is also linked to cell membrane potassium and calcium channels in a complex manner such that ligand binding influences the intracellular concentration of these ions and the cell membrane polarization (14). Data linking SSTR5 to phospholipase-related signal transduction has also been presented (18).

The phosphoprotein phosphatase activity associated with SSTR2 is regarded as a particularly interesting activity in the context of antineoplastic effects of somatostatin analogs. Prior to reports linking this activity to somatostatin signal transduction, it was recognized that blockade of phosphoprotein phosphatase by vanadate stimulated cellular proliferation (51). Such blockade enhances the physiological consequences of the binding of growth factors such as epidermal growth factor (EGF) and insulin-like growth factors (IGFs) to cell-surface mitogen receptors that utilize tyrosine kinase signal transduction pathways by preventing dephosphorylation of the phosphorylated substrates that serve as second messengers. Conversely, somatostatin-receptor linked upregulation of phosphoprotein phosphatase activity would be expected to attenuate mitogenic signals by favoring dephosphorylation of intermediates phosphorylated by mitogen receptors of the tyrosine kinase class.

\section{Indirect Mechanisms of Action}

Early evidence that somatostatin analogs could inhibit the proliferation of somatostatin receptor-negative neoplasms came from Reubi's demonstration that octreotide 
was a potent inhibitor of Swarm chondrosarcoma, an experimental neoplasm that lacks somatostatin binding sites (33). These chondrosarcoma cells have abundant IGF-I receptors, and it was proposed that this growth inhibition is mediated indirectly through octreotide-induced inhibition of pituitary GH secretion, which in turn leads to reduction in GH-dependent hepatic IGF-I expression.

Subsequently, considerable evidence has been presented to support the view that the growth hormone-IGF-I axis has an important influence on the biologic behavior of many common neoplasms. Many types of neoplastic cells display IGF-I receptors and respond mitogenically to insulin-like growth factors present in their microenvironment $(52,53)$. In vivo studies have demonstrated that a blocking antibody directed against the IGF-I receptor reduces proliferation of certain IGF-responsive neoplasms (54). Further evidence comes from experiments with mice homozygous for the recessive 'lit' mutation of the growth hormonereleasing hormone $(\mathrm{GHRH})$ receptor $(55,56)$. These animals are IGF-I deficient, and human breast cancer cells inoculated into immunodeficient 'lit/lit' hosts show significantly decreased growth relative to cells inoculated into control IGF-I-replete hosts (57). In a separate experimental system $(58,59)$, it has been shown that both local growth and metastatic behavior of IGF-I responsive sarcomas are reduced by hypophysectomy and restored by administration of growth hormone. These lines of evidence support the hypothesis that aggressive behavior of certain neoplasms may be reduced by targeting the host GH-IGF-I axis. Pharmacological strategies that have been proposed to this end include not only the use of somatostatin analogs (60), but also growth hormone-releasing hormone antagonists (61), growth hormone antagonists (62), IGF binding proteins (63), and IGF-I antagonists (64). However, at present, only somatostatin analogs are available for clinical trials.

The suppressive effect of octreotide on serum IGF-I level may be related to direct inhibition of IGF-I gene expression as well as to suppression of $\mathrm{GH}$ with subsequent reduction in GH-dependent IGF-I expression in liver (11, 65). The direct suppressive action remains incompletely characterized, and it is possible that the drug suppresses paracrine and autocrine IGF-I expression as well as circulating IGF-I levels. While it would be predicted that neoplasms that constitutively secrete ligands for the IGF-I receptor in an uncontrollable autocrine fashion would be minimally impacted by reduction in IGF-I expression by host tissues, the cited experimental data suggest that at least a subset of neoplasms do depend on host sources of IGFs.

Initial clinical studies of suppression of the GH-IGF-I axis by somatostatin analogs focused on suppression of the abnormally high secretion of growth hormone that is characteristic of acromegaly. Somatostatin analogs have proven to be effective suppressors of secretion of GH secretion in a sizable proportion of acromegalics (20). In the present context, however, the challenge is to suppress normal GH secretion. This generally requires a higher dose of somatostat- in analog than that needed to suppress the abnormally high $\mathrm{GH}$ secretion seen in acromegaly. The difference in doseresponse is not surprising, as only in the nonacromegalic situation will there be a physiological response to oppose the action of the somatostatin analog on GH secretion. Such responses might include enhanced GHRH secretion by hypothalamic neurons or enhanced responsivity to GHRH by somatotrophs. Both clinical (60) and experimental (66) studies suggest that even treatment with a high dose of somatostatin analog generally suppresses serum IGF-I levels in nonacromegalic individuals by only approximately $30 \%$, a much smaller absolute reduction than that typically seen in the treatment of acromegaly. This reduction can be enhanced in experimental systems by co-administration of tamoxifen (66). It is possible that co-administration of GHRH antagonists (61) could further increase suppression of the GH-IGF-I axis. Somatostatin analogs have been noted to stimulate the secretion of certain IGF binding proteins, an action which has been proposed to attenuate IGF-I bioactivity independantly of the suppressive effect of the analogs on IGF-I levels (67-69). Although the developmental effects of inactivation of the IGF-I gene are known to be much more severe (70) than those associated with the lit mutation $(55,56)$, the deficiency of GH and IGF-I induced by chronic octreotide therapy in adults undergoing long-term treatment for carcinoid syndrome has not been noted to result in a clinically significant deficiency syndrome.

It has been proposed that somatostatin analogs can act indirectly as antineoplastic agents by inhibition of angiogenesis $(71,72)$. Certainly, antiangiogenesis has been shown to be a promising therapeutic approach (73). As peritumoral vessels exhibit somatostatin receptors (35) and neovascularization is enhanced by IGF-I (74), inhibition of angiogenesis itself might involve direct and/or indirect actions of somatostatin analogs on the nontransformed cells comprising the microvasculature of neoplastic tissue.

A direct pathway by which somatostatin analogs can induce apoptosis via interaction with SSTR3 has already been reviewed above. Also noteworthy in this context is the fact that IGF-I is recognized as a potent antiapoptotic factor (75-77). Thus, the inhibitory effects of somatostatin analogs on IGF-I gene expression may enhance their 'direct' apoptosis-inducing action, and contribute to the apoptotic effects of these compounds seen in experimental systems (78-81).

Recent epidemiological reports $(82,82 \mathrm{a})$ raise the possibility of an indication of somatostatin analogs in cancer prevention for certain individuals. It is well known that there is considerable heterogeneity in serum IGF levels between normal adults (83). A blinded prospective study documented a 3.6-fold greater premenopausal breast cancer risk in individuals in the highest as compared to lowest tertile of IGF-I levels (82). Prostate cancer risk also appears to be positively correlated with IGF-I levels (82a). If these observations are confirmed, the possibility of interventions to reduce the risk related to high IGF-I level will deserve attention and somatostatin analogs will be obvious candidates in this regard. 


\section{Somatostatin Analogs as Drug Candidates in Oncology}

Antiestrogens, progestins, and LH-RH analogs are commonly prescribed compounds that provide precedents for control of certain tumors of the breast and prostate by noncytotoxic means. However, there is an obvious clinical need to improve the efficacy of these therapies, and to determine if the paradigm of noncytotoxic control of neoplastic behavior can be extended to other common cancers for which current treatments are inadequate. Somatostatin analogs are logical drug candidates in this regard for several reasons. Clinical experience with long-term administration of somatostatin analogs over the past decade in patients with acromegaly and carcinoid syndrome has supported early reports that suggested that these compounds have favorable toxicity profiles relative to current antineoplastic agents, and also have demonstrated therapeutic activity in these specific conditions. Recent scientific advances have defined the molecular basis for both direct and indirect mechanisms of action. Finally, there is considerable evidence $(4,5)$ from many in vitro and in vivo model systems for antineoplastic activity of somatostatin analogs for neoplasms of breast, prostate, pancreas, colon, lung, and other common solid tumors for which current treatments are inadequate.

Early clinical studies with somatostatin analogs RC160 and octreotide were uncontrolled trials carried out in patients with advanced pancreatic or other cancers, without determination and subtyping of somatostatin receptors (3). Investigators working with octreotide saw no activity in some studies (for example, see Ref. 84), and evidence for modest activity in others (for example, see Ref. 85). Early trials of RC-160 showed tumor stabilization and improvement in the quality of life in some patients with pancreatic cancer (86), but collectively suggest that RC-160 at the dosages employed was not adequate for inducing effective palliation in most patients with advanced pancreatic cancer (87). On the basis of these and similar early results, clinical trials now under way are being conducted as more formal randomized studies, and also differ from early studies in that many are examining somatostatin analogs used in combination with other drugs and/or as initial adjuvant treatment in relatively low tumor burden settings, and/or are exploring higher doses than those previously used.

Careful attention must be given to dose and patient compliance in any trial. Monthly depot formulations of somatostatin analogs (for example, see Ref. 88) offer major advantages in this regard over earlier preparations that required multiple subcutaneous injections on a daily basis. In standard evaluations of novel compounds for potential application in oncology, it is necessary to perform preliminary toxicity and dose-finding studies prior to launching definitive trials. Extensive prior clinical experience with somatostatin analogs in acromegaly and carcinoid syndrome has shown that these agents are relatively well tolerated both acutely and chronically. Unlike cytotoxic compounds, it is not possible to define a suitable dose on the basis of maximal tolerable adverse effects, as there is no dose-limiting toxicity. Accordingly, as a rough guide for dosage selection, it has been proposed to use doses that achieve serum drug levels similar to those seen in preclinical in vivo models where antineoplastic activity is seen.

Preclinical data suggesting useful interactions between somatostatin analogs and other agents $(10,89)$ are of potential relevance to design of randomized clinical trials, given the limitations of single agent somatostatin analogs therapy seen in early clinical studies. Furthermore, patients tend to accept randomization between treatment with an approved drug and treatment with a combination of the approved drug and a novel agent more readily than they participate in trials with other designs such as randomization between a research compound and a drug that has documented antineoplastic activity.

Consideration must be given to the stage of disease and the nature of prior treatments in defining eligibility criteria for patient entry to clinical trials. A few small studies indicate little or no efficacy of somatostatin analogs when used in heavily pretreated patients with advanced metastatic breast, gastrointestinal, and lung cancer (reviewed in Ref. 90). The vast majority of current antineoplastic agents are also ineffective in this setting, and these studies simply provide evidence that somatostatin analogs are not special in this regard. In view of preclinical evidence suggesting that somatostatin analogs are more efficacious when used in hosts with relatively low tumor burdens, it would be particularly appropriate to carry out trials in various postsurgical adjuvant settings, rather than confining clinical studies to patients with macrometastatic disease.

At present, there is evidence that both direct and indirect mechanisms of action contribute to the antineoplastic actions of somatostatin analogs; for example, there is good evidence for a relationship between phosphotyrosine phosphatase activity associated with SSTR-2 and direct antiproliferative actions (18). However, it also is clear that somatostatin analogs administered systemically can inhibit the growth of somatostatin receptor-negative neoplasms (33), indicating that indirect antiproliferative actions exist. These direct and indirect growth inhibitory mechanisms of action are not mutually exclusive and may be additive or even synergistic (6). Therefore, neoplasms that are susceptible to both mechanisms are particularly appropriate for study in randomized clinical trials. Estrogen-receptor positive breast cancer is an example of a logical target neoplasm from this perspective: In vivo binding of labeled octreotide to human breast cancers are strongly suggestive that these tumors express SSTR-2 (41), and in situ hybridization studies are consistent with these data (91), suggesting the possibility of 'direct' growth inhibition. There is separate evidence that these neoplasms are mitogenically responsive to exogenous IGFs $(54,57)$, leaving open the possibility that 'indirect' inhibitory actions of somatostatin analogs on the IGF sys- 
tem of mitogens may contribute to antiproliferative effects of somatostatin analog treatment.

Interestingly, there are specific rationales with respect to both the direct and the indirect mechanisms of action to study somatostatin analogs co-administered with antiestrogens. With respect to the direct mechanisms, in vitro studies demonstrate that the antiproliferative action of somatostatin analogs on the MCF-7 estrogen-receptor positive human breast cancer cell line are maximized in the absence of estradiol and attenuated in its presence (40). More recent work (92) provides direct evidence for potentiation by octreotide of the antiproliferative effect of the antiestrogen tamoxifen on MCF-7 cells. Studies are ongoing to clarify the physiology underlying this observation, but regardless of mechanism, these results provide an obvious rationale for combined antiestrogen-somatostatin therapy. With respect to the indirect mechanism, both tamoxifen (93) and octreotide (60) suppress IGF-I when used as single agents, and both in vivo and clinical studies have demonstrated that suppression of IGF-I gene expression and serum levels is maximum when the two compounds are administered together $(66,94)$. The well-characterized DMBA-induced mammary cancer model expresses IGF-I receptors, somatostatin receptors, and estrogen receptors. This model has been used successfully to predict clinical activity of a number of compounds now used clinically (95). When the DMBA system is used to generate a model of high tumor burden breast cancer, only insignificant activity of octreotide given as single agent is seen (96). On the other hand, when this model is used to generate a model of low tumor burden breast cancer, octreotide has significant antineoplastic activity as a single agent although this is not greater than that of presently available compounds such as tamoxifen (6). However, the antineoplastic activity of the combination of octreotide and tamoxifen is significantly greater than that of either compound alone (6).

These results suggest a clinical trial design involving randomization of breast cancer patients between antiestrogen therapy and combined antiestrogen-somatostatin analog therapy as post-surgical adjuvant treatment. Such a trial design has practical advantages as well as a scientific rationale. It allows for the somatostatin analog to be used as a component of initial therapy rather than being evaluated in heavily pretreated patients, and allows a randomization scheme that is acceptable to patients. Major multicenter trials based on this general design were launched in late 1996, and will compare tamoxifen alone to the combination of tamoxifen and octreotide in both the post-surgical adjuvant and early metastatic disease settings. These trials represent the first large-scale randomized evaluation of a somatostatin analog in post-surgical adjuvant treatment of cancer.

Although prostate cancer has been studied preclinically to a lesser extent than breast cancer, there are reports (for example, see Refs. 3, 97, 98) that suggest a rationale for analogous clinical trials comparing treatment with LH-RH analogs to combined therapy with an LH-RH analog and a somatostatin analog (99). In contrast, for clinical trials targeting other neoplasms such as renal or pancreatic cancers, high dose single-agent-therapy somatostatin therapy may be acceptable as first-line treatment for metastatic disease, given the absence of demonstrated efficacious alternatives of low toxicity. Single agent activity has been demonstrated in an interesting but relatively small group of lymphoma patients (100), and this observation requires follow-up.

Combinations of chemotherapy with somatostatin analogs are also receiving attention, both because of the demonstrated ability of octreotide to reduce gastrointestinal toxicity associated with certain cytotoxic agents (101), and because of early evidence of additive antineoplastic activity (89). Thus in experimental studies using hamsters with ductal pancreatic cancers induced by $N$-nitroso-bis(2-oxopropyl)amine (BOP), a 76\% inhibition of tumorous pancreas weight, a significant decrease in the number of tumor nodules, an increased amount of stroma, and enhanced apoptosis were observed after therapy with somatostatin analog RC-160 plus 5-fluorouracil (5-FU) (102). These tumor inhibition parameters were superior to those in the group treated with 5-FU alone or with RC-160 alone (102). One mechanism underlying a favorable interaction between somatostatin analogs and cytotoxic agents may relate to maximizing apoptosis by induction of DNA damage and separately by somatostatin receptor-mediated mechanisms (8). A formal randomized clinical trial comparing 5-FU + placebo to 5-FU + octreotide with end points that include survival and quality of life is now in progress.

The presence of binding sites for somatostatin in certain cancers could also be utilized for targeting various chemotherapeutic agents linked to suitable somatostatin analogs. In an experimental study, an early cytotoxic analog AN-51 consisting of methotrexate (MTX) linked to somatostatin octapeptide analog D-Phe-Cys-Tyr-D-Trp-Lys-Val-Cys$\mathrm{Thr}-\mathrm{NH}_{2}$ (RC-121) at $\mathrm{N}$-terminus, was tested in nude mice bearing transplanted Mia PaCa-2 human pancreatic cancers (103). The treatment with AN-51 inhibited tumor growth, whereas methotrexate or RC-121 administered singly had no significant effect (103). Recently, the synthesis of modern cytotoxic analogs of LH-RH and bombesin targeted against tumors that bear receptors for these peptides was reported $(104,105)$. These analogs contain doxorubicin or 2-pyrrolinodoxorubicin (a derivative 500-1000 times more potent than doxorubicin (106)) and appear to have a superior therapeutic index when compared to the corresponding free cytotoxic agents in the treatment of tumors that possess receptors for the carrier peptides. The synthesis of corresponding cytotoxic analogs of somatostatin is in progress. These highly potent cytotoxic analogs of somatostatin are being designed as targeted antitumor agents for the treatment of cancers that possess receptors for somatostatin. The hypothesis that somatostatin analogs can be used to deliver radiotherapeutic isotopes to somatostatin receptor positive tumors is also under active investigation (42). 
Despite recent advances in research regarding the molecular pharmacology and physiology of somatostatin analogs, many important issues remain poorly understood. One example concerns mechanisms underlying the development of tolerance to certain actions of somatostatin analogs (e.g., effects on gastrointestinal motility), as well as the relative lack of tolerance even over long periods of administration to other effects, such as inhibition of growth hormone output. The relative importance of direct and indirect antineoplastic mechanisms, and the identification of molecular markers to identify those neoplasms that are likely to respond therapeutically via each mechanism are needed. A specific issue in this regard concerns the significance of expression of mRNAs for somatostatin receptors by neoplastic cells. It will be important to determine to what extent such gene expression generally implies expression of a functional receptor protein and an intact signal transduction mechanism.

In view of these and other areas of uncertainty, some may feel that it is premature to proceed with clinical trials of somatostatin analogs in non-neuroendocrine neoplastic diseases. However, there is clear precedent for doing so. When clinical trials of antiestrogens were launched, knowledge of their mechanism of action was very incomplete. Even now, after more than two decades of clinical use, research is ongoing regarding molecular mechanisms, the design of improved compounds, and the optimum manner to use these agents for cancer treatment and prevention. Somatostatin analogs themselves provide further precedent for proceeding with clinical research: their efficacy for certain currently approved indications such as carcinoid syndrome was demonstrated in clinical trials in the absence of a complete description of the molecular mechanisms involved. Only controlled trials can demonstrate the clinical relevance of the antineoplastic activity of somatostatin analogs demonstrated in laboratory models, or the lack thereof. Ideally, such clinical trials should also serve to contribute to the advancement of basic research because they provide a unique opportunity to collect informative serum and tissue samples prior to and during administration of somatostatin analogs.

We thank Noreen Majeed for assistance with manuscript preparation.

1. Schipper H, Goh CR, Wang TL. Shifting the cancer paradigm: Must we kill to cure? J Clin Oncol 13:801-807, 1995.

2. Schipper H, Turley E, Baum M. A new biological framework for cancer research. Lancet 348:1149-1151, 1996.

3. Schally AV, Comaru-Schally AM. Hypothalamic and other peptine hormones. In: Holland JF, Frei EI, Bast RCJ, Kufe DE, Morton DL, Weichselbaum RR, Ed. Cancer Medicine, 4th ed. Baltimore: Williams and Wilkins, pp1067-1085, 1997.

4. Weckbecker G, Raulf Stolz B, Bruns C. Somatostatin analogs for diagnosis and treatment of cancer. Pharmacol Ther 60:245-264, 1993.

5. Schally AV. Oncological applications of somatostatin analogs. Cancer Res 48:6877-6885, 1988.

6. Weckbecker G, Tolcsvai L, Stolz B, Pollak M, Bruns C. Somatostatin analog octreotide enhances the antineoplastic effects of tamoxifen and ovariectomy on 7,12-dimethylbenz(a)anthracene-induced rat mammary carcinomas. Cancer Res 54:6334-6337, 1994.

7. Pollak M, Ingle J, Suman V, Kugler J. Rationale for combined antiestrogen-somatostatin analog therapy of breast cancer. In: Salmon SE, Eds. Adjuvant Therapy of Cancer VIII: Proceedings of the Eighth International Conference on the Adjuvant Therapy of Cancer. pp 145-152. Philadelphia: J.B. Lippincott, 1997.

8. Sharma K, Patel YC, Srikant C. Subtype specific induction of wild type p53 and apoptosis, but not cell cycle arrest, by human somatostatin receptor 3. Mol Endocrinol 10:1688-1696, 1996.

9. Liebow C, Reilly C, Serrano M, Schally AV. Somatostatin analogs inhibit growth of pancreatic cancer by stimulating tyrosine phosphatase. Proc Natl Acad Sci USA 85:1-22, 1988.

10. Pollak M. Enhancement of the antineoplastic effects of tamoxifen by somatostatin analogs. Digestion 57:(Suppl 1)29-33, 1996.

11. Serri O, Brazeau P, Kachra Z, Posner B. Octreotide inhibits insulinlike growth factor-I hepatic gene expression in the hypophysectomized rat: Evidence for a direct and indirect mechanism of action. Endocrinology 130: 1816-1821, 1992.

12. Buscail L, Delesque N, Esteve JP, Saint-Laurent N, Prats H, Clerc P, Robberecht P, Bell GI, Liebow C, Schally AV, Vaysse N, Susini C. Stimulation of tyrosine phosphatase and inhibition of cell proliferation by somatostatin analogs: Mediation by human somatostatin receptor subtypes SSTR1 and SSTR2. Proc Natl Acad Sci USA 91:2315-2319, 1994.

13. Patel YC, Greenwood MT, Panetta R, Hukovic N, Grigorakis S, Robertson LA, Srikant CB. Molecular biology of somatostatin receptor subtypes. Metabolism 45(Suppl 1):31-38, 1996.

14. Patel YC, Greenwood MT, Panetta R, Demchyshyn L, Niznik H, Srikant CB. The somatostatin receptor family. Life Sci 57:1249$1265,1995$.

15. Schonbrunn A, Gu YZ, Dournard P, Beaudet A, Tannenbaum GS, Brown PJ. Somatostatin receptor subtypes: Specific expression and signalling properties. Metabolism 45(Suppl 1):8-11, 1996.

16. Reisine T, Bell GI. Molecular biology of somatostatin receptors. Endocrine Rev 16:427-442, 1995.

17. Reubi JC, Laissue JA. Multiple actions of somatostatin in neoplastic disease. Trends Pharmacol Sci 16:110-115, 1995.

18. Buscail L, Esteve JP, Saint-Laurent N, Bertrand V, Reisine T, O'Carroll AM, Bell GI, Schally AV, Vaysse N, Susini C. Inhibition of cell proliferation by the somatostatin analog RC-160 is mediated by somatostatin receptor subtypes SSTR2 and SSTR5 through different mechanisms. Proc Natl Acad Sci USA 92:1580-1584, 1995.

19. Bruns C, Weckbecker G, Raulf F, Kaupmann K, Schoeffter P, Hoyer $\mathrm{D}$, Lubbert H. Molecular pharmacology of somatostatin-receptor subtypes. Ann N Y Acad Sci 733:138-146, 1994.

20. Lamberts SW, van der Lely A, Deherder WW, Hofland LJ. Drug therapy: Octreotide. New Eng J Med 334:246-254, 1996.

21. Reichlin S. Somatostatin. New Eng J Med 309:1495-1501, 1983.

22. Schally AV, Coy DH, Meyers CA. Hypothalamic regulatory hormones. Annu Rev Biochem 47:89-128, 1978.

23. Berelowitz M, LeRoith D, von Schenk H, Newgard C, Szabo M, Frohman LA, Shiloach J, Roth J. Somatostatin-like immunoactivity and biological activity is present in Tetrahymena pyriformis, a ciliated protozoan. Endocrinol 110:1939-1944, 1982.

24. Brazeau P, Vale W, Burgus R, Ling N, Butcher M, Rivier J, Guillemin R. A hypothalamic polypeptide that inhibits the secretion of pituitary growth hormone. Science 179:77-79, 1973.

25. Hobart P, Crawford R, Shen L, Pictet R, Rutter WJ. Cloning and sequence analysis of cDNAs encoding two distinct somatostatin precursors found in the endocrine pancreas of anglerfish. Nature 288:137-141, 1980.

26. Lamberts SWJ, Krenning EP, Reubi JC. The role of somatostatin and its analogs in the diagnosis and treatment of tumours. Endocrine Rev 12:450-482, 1991.

27. Bauer W, Briner U, Doepfner W, Haller R, Huguenin R, Petcher TJ, Press J. SMS 201-995: A very potent and selective octapeptide ana$\log$ of somatostatin with prolonged action. Life Sci 31:1133-1140, 1982.

28. Veber DF, Freidlinger RM, Perlow DS, Paleveda WJ Jr., Holly FW, Strachan RG, Nutt RF, Arison BH, Homnick C, Randall WC, Glitzer MS, Saperstein R, Hirschmann R. A potent cyclic hexapeptide analog of somatostatin. Nature 292:55-58, 1981.

29. Veber DF, Saperstein R, Nutt RF, Freidinger RM, Brady SF, Curley 
P, Perlow DS, Paleveda WJ, Colton CD, Zacchei AG. A super active cyclic hexapeptide analog of somatostatin. Life Sci 34:1371-1378, 1984.

30. Cai RZ, Szoke B, Lu R, Fu D, Redding TW, Schally AV. Synthesis and biological activity of highly potent octapeptide analogs of somatostatin. Proc Natl Acad Sci U S A 83:1896-1900, 1986.

31. Bell GI, Reisine T. Molecular biology of somatostatin receptors Trends Neurosci 16:34-38, 1993.

32. Coy DH, Taylor JE. Receptor-specific somatostatin analogs: Correlations with biological activity. Metabolism 45(Suppl 1):21-23, 1996.

33. Reubi JC. A somatostatin analog inhibits chondrosarcoma and insulinoma tumour growth. Acta Endocrinol 109:108-114, 1985.

34. Reubi JC, Waser B, Schaer JC, Markwalder R. Somatostatin receptors in human prostate and prostate cancer. J Clin Endocrinol Metab 80:2806-2814, 1995 .

35. Reubi JC, Schaer JC, Laissue J, Waser B. Somatostatin receptors and their subtypes in human tumors and in peritumoral vessels. Metabolism 45(Suppl 1):39-41, 1996.

36. Vikic-Topic S, Raisch KP, Kvols LK, Vuk-Pavlovic S. Expression of somatostatin receptor subtypes in breast carcinoma, carcinoid tumor, and renal cell carcinoma. J Clin Endocrinol Metab 80:2974-2979, 1995.

37. Buscail L, Saint-Laurent N, Chastre E, Vaillant JC, Gespach C, Capella G, Kalthoff H, Lluis F, Vaysse N, Susini C. Loss of sst2 somatostatin receptor gene expression in human pancreatic and colorectal cancer. Cancer Res 56:1823-1827, 1996.

38. Maini CL, Sciuto R, Tofani R A, Ferraironi A, Carapella CM, Occhipinti E, Mottolese M, Crecco M. Somatostatin receptor imaging in CNS tumours using 111In-octreotide. Nucl Med Commun 16:756766, 1995.

39. Fekete M, Wittliff JL, Schally AV. Characteristics and distribution of receptors for [D-TRP6]-luteinizing hormone-releasing hormone, somatostatin, epidermal growth factor, and sex steroids in 500 biopsy samples of human breast cancer. J Clin Lab Anal 3:137-147, 1989.

40. Setyono-Han B, Henkelman MS, Foekens JA, Klijn GM. Direct inhibitory effects of somatostatin (analogs) on the growth of human breast cancer cells. Cancer Res 47:1566-1570, 1987.

41. van Eijck $\mathrm{CH}$, Krenning EP, Bootsma A, Lindemans J, Jeekel J, Reubi JC, Lamberts SW. Somatostatin-receptor scintigraphy in primary breast cancer. Lancet 343:640-643, 1994.

42. Krenning EP, Kooij PPM, Pauwels O, Breeman WA, Postema PT, De Harder WW, Valkema R, Kwekkeboom DJ. Somatostatin receptor: Scintigraphy and radionuclide therapy. Digestion 57(Suppl 1):57-62, 1996.

43. Krenning EP, Kwekkeboom DJ, Bakker WH, Breeman WAP, Kooij PPM, Oei HY, van Hagen M, Postema PTE, de Jong M, Reubi JC, Visser TJ, Reijis AEM, Hofland LJ, Koper JW, Lamberts SWJ. Somatostatin receptor scintigraphy with [ ${ }^{111}$ In-DTPA-D-Phe $\left.{ }^{1}\right]-$ and [ ${ }^{123} \mathrm{Tyr}^{3}$ ]-octreotide: The Rotterdam experience with more than 1000 patients. Eur J Nucl Med 20:716-731, 1993.

44. Palmieri G, Lastoria S, Colao A, Vergara E, Varrella P, Biondi E, Selleri C, Catalano L, Lombardi G, Bianco AR, Salvatore M. Successful treatment of a patient with a thymoma and pure red-cell aplasia with octreotide and prednisone. N Engl J Med 336:263-265, 1997.

45. Breeman WAP, Hofland LJ, van der Plujim M, van Koetsveld PM, de Jong M, Setyono-Han B, Bakker WH, Kwekkeboom DJ, Visser TJ, Lamberts SWJ, Krenning EP. A new radiolabelled somatostatin ana$\log \left[{ }^{111}\right.$ In-DTPA-D-Phe $\left.{ }^{1}\right]$ RC-160: Preparation, biological activity, receptor scintigraphy in rats and comparison with [ ${ }^{11}$ In-DTPA-D$\mathrm{Phe}^{1}$ loctreotide. Eur J Nucl Med 21:328-335, 1994.

46. Reubi JC, Laissue J, Krenning E, Lamberts SW. Somatostatin receptors in human cancer: Incidence, characteristics, functional correlates and clinical implications. J Steroid Biochem Mol Biol 43:27-35, 1992.

47. Foekens JA, Portengen H, van Putten WL, Trapman AM, Reubi JC, Alexieva-Figusch J, Klijn JG. Prognostic value of receptors for insulin-like growth factor 1 , somatostatin, and epidermal growth factor in human breast cancer. Cancer Res 49:7002-7009, 1989.

48. Zhang CY, Yokogoshi Y, Yoshimoto K, Fujinaka Y, Matsumoto K, Saito $S$. Point mutation of the somatostatin receptor 2 gene in the human small cell lung cancer cell line COR-L103. Biochem Biophys Res Commun 210:805-815, 1995.
49. Srikant CB, Patel YC. Receptor binding of somatostatin-28 is tissue specific. Nature 294:259-260, 1981.

50. Tran VT, Beal MF, Martin JB. Two types of somatostatin receptors differentiated by cyclic somatostatin analogs. Science 228:492-495, 1985.

51. Klarlund JK. Transformation of cells by an inhibitor of phosphatases acting on phosphotyrosine in proteins. Cell 41:707-717, 1985.

52. Macaulay VM. Insulin-like growth factors and cancer. Br J Cancer 65:311-320, 1992

53. Cullen KJ, Yee D, Rosen N. Insulin-like growth factors in human malignancy. Cancer Invest 9:443-454, 1991.

54. Arteaga CL, Kitten LJ, Coronado EB, Jacobs S, Kull FC, Allred DC, Osborne CK. Blockade of the type 1 somatomedin receptor inhibits growth of human breast cancer cells in athymic mice. J Clin Invest 84:1418-1423, 1989.

55. Wajnrajch MP, Gertner JM, Harbison MD, Chua SC, Leibel RL. Nonsense mutation in the human growth hormone releasing hormone receptor causes growth failure analogous to the little (lit) mouse. Nat Genet 12:88-90, 1996

56. Jansson JO, Downs TR, Beamer WG, Frohman LA. Receptorassociated resistance to growth hormone-releasing factor in dwarf "little" mice. Science 232:511-512, 1986.

57. Yang XF, Beamer W, Huynh HT, Pollak M. Reduced growth of human breast cancer xenografts in hosts homozygous for the 'lit' mutation. Cancer Res 56:1509-1511, 1996.

58. Pollak M, Sem A, Richard M, Tetenes E, Bell R. Inhibition of metastatic behavior of murine osteosarcoma by hypophysectomy. J Natl Cancer Inst 84:966-971, 1992.

59. Sekyi-Otu A, Bell R, Andrulis IL, Pollak M. Metastatic behaviour of the RIF-1 murine fibrosarcoma: Inhibited by hypophysectomy and partially restored by growth hormone replacement. J Natl Cancer Inst 86:628-632, 1994

60. Pollak M, Polychronakos C, Guyda H. Somatostatin analog SMS 201-995 reduces serum IGF-I levels in patients with neoplasms potentially dependent on IGF-I. Anticancer Res 9:889-892, 1989.

61. Zarandi M, Horvath JE, Halmos G, Pinski J, Nagy A, Groot K, Rekasi Z, Schally AV. Synthesis and biological activities of highly potent antagonists of growth hormone-releasing hormone. Proc Natl Acad Sci USA 91:12298-12302, 1994.

62. Harding PA, Wang X, Okada S, Chen WY, Wan W, Kopchick JJ. Growth hormone $(\mathrm{GH})$ and a $\mathrm{GH}$ antagonist promote $\mathrm{GH}$ receptor dimerization and internalization. J Biol Chem 271:6708-6712, 1996.

63. McGuire WL, Jackson JG, Figueroa JA, Shimasaki S, Powell DR, Yee D. Regulation of insulin-like growth factor-binding protein (IGFBP) expression by breast cancer cells: Use of IGFBP-I as an inhibitor of insulin-like growth factor action. J Natl Cancer Inst 84:13361341, 1992.

64. Pietrzkowski Z, Wernicke D, Porcu P, Jameson BA, Baserga R. Inhibition of cellular proliferation by peptide analogs of IGF-I. Cancer Res 52:6447-6451, 1992.

65. Ambler GR, Butler AA, Padmanabhan J, Breier BH, Gluckman PD. The effects of octreotide on GH receptor and IGF-I expression in the GH-deficient rat. J Endocrinol 149:223-231, 1996.

66. Huynh HT, Pollak M. Enhancement of tamoxifen-induced suppression of insulin-like growth factor I gene expression and serum level by a somatostatin analog. Biochem Biophys Res Commun 203:253259, 1994.

67. Ezzat S, Ren SG, Braunstein GD, Melmed S. Octreotide stimulates insulin-like growth factor-binding protein-1: A potential pituitaryindependent mechanism for drug action. J Clin Endocrinol Metab 75:1459-1463, 1992.

68. Flyvbjerg A, Schuller AG, van Neck JW, Groffen C, Orskov H, Drop SL. Stimulation of hepatic insulin-like growth factor-binding protein- 1 and -3 gene expression by octreotide in rats. J Endocrinol 147:545-551, 1995.

69. de Herder WW, Uitterlinden P, van der Lely AJ, Hofland LJ, Lamberts SW. Octreotide, but not bromocriptine, increases circulating insulin-like growth factor binding protein 1 levels in acromegaly. Eur J Endocrinol 133:195-199, 1995.

70. Woods KA, Camacho-Hubner C, Savage MO, Clark AJ. Intrauterine growth retardation and postnatal growth failure associated with deletion of the insulin-like growth factor I gene. N Engl J Med 335:1363-1367, 1996.

71. Patel PC, Barrie R, Hill N, Landeck S, Kurozawa D, Woltering EA. 
Postreceptor signal transduction mechanisms involved in octreotideinduced inhibition of angiogenesis. Surgery 116:1148-1152, 1994.

72. Barrie R, Woltering EA, Hajarizadeh H, Mueller C, Ure T, Fletcher WS. Inhibition of angiogenesis by somatostatin and somatostatin-like compounds is structurally dependent. J Surg Res 55:446-450, 1993.

73. Folkman J. Clinical applications of research on angiogenesis. N Engl J Med 333:1757-1763, 1995.

74. Nakao-Hayashi J, Ito H, Kanayasu T, Morita I, Murota S. Stimulatory effects of insulin and insulin-like growth factor I on migration and tube formation by vascular endothelial cells. Atherosclerosis 92: 141149, 1992.

75. Baserga R. The insulin-like growth factor I receptor: A key to tumor growth? Cancer Res 55:249-252, 1995.

76. Resnicoff M, Abraham D, Yutanawiboonchai W, Rotman HL, Kajstura J, Rubin R, Zoltick P, Baserga R. The insulin-like growth factor I receptor protects tumor cells from apoptosis in vivo. Cancer Res 55:2463-2469, 1995.

77. Sell C, Baserga R, Rubin R. Insulin-like growth factor I (IGF-I) and the IGF-I receptor prevent etoposide-induced apoptosis. Cancer Res 55:303-306, 1995.

78. Szende B, Lapis K, Redding TW, Srkalovic G, Schally AV. Growth inhibition of MXT mammary carcinoma by enhancing programmed cell death (apoptosis) with analogs of LH-RH and somatostatin. Breast Cancer Res Treat 14:307-314, 1989.

79. Szepeshazi K, Milovanovic S, Lapis K, Groot K, Schally AV. Growth inhibition of estrogen independent MXT mouse mammary carcinomas in mice treated with an agonist or antagonist of LH-RH, an analog of somatostatin, or a combination. Breast Cancer Res Treat 21:181-192, 1992

80. Szende B, Srkalovic G, Schally AV, Lapis K, Groot K. Inhibitory effects of analogs of luteinizing hormone-releasing hormone and somatostatin on pancreatic cancers in hamsters. Cancer 65:2279-2290, 1990.

81. Szepeshazi K, Schally AV, Halmos G. Apoptosis in pancreatic cancers of hamsters. Intl J Pancreatology 16:282-287, 1994.

82. Hankinson S, Pollak M, Michaud D, Willet W, Speizer F, the Nurses' Health Study Research Group, Harvard University, Boston. A prospective assessment of plasma insulin-like growth factor levels and breast cancer risk [abstract]. Proc Annual Meeting of the Society of Epidemiological Research, Edmonton, 1997.

82a. Chan J, Stampfer M, Giovannucci E, Gann P, Ma J, Wilkinson P, Hennekens C, Pollak M. Circulating insulin-like growth factor I and prostate cancer risk: A prospective study. Science, in press, 1998.

83. Juul A, Bang P, Hertel N. Serum insulin-like growth factor I in 1030 healthy children, adolescents, and adults: Relation to age, sex, stage of puberty, testicular size, and body mass index. J Clin Endocrinol Metab 78:1744-752, 1995 .

84. Logothetis CJ, Hossan EA, Smith TL. SMS 201-995 in the treatment of refractory prostatic carcinoma. Anticancer Res 14:2731-2734, 1994.

85. Rosenberg L, Barkun AN, Denis MH, Pollak M. Low dose octreotide and tamoxifen in the treatment of adenocarcinoma of the pancreas. Cancer 75:23-28, 1995.

86. Poston GH, Schally AV. Somatostatin analogs and pancreatic cancer. Intl J Pancreatology 14:64-66, 1993.

87. Schally AV, Szepeshazi K, Qin Y, Halmos G, Ertl T, Groot K, Cai $\mathrm{RZ}$, Liebow C, Poston GH. Antitumor effects of analogs of somatostatin and antagonists of bombesin/GRP in experimental models of pancreatic cancer. Intl J Pancreatology 16:246-249, 1994.

88. Grass P, Marbach P, Bruns C, Lancranjan I. Sandostatin LAR in acromegaly: Pharmacokinetic and pharmacodynamic relationships. Metabolism 45(Suppl 1):27-30, 1996.

89. Weckbecker G, Raulf F, Tolcsvai L, Bruns C. Potentiation of the antiproliferative effects of anti-cancer drugs by octreotide in vivo and in vitro. Digestion 57(Suppl 1):4:27-30, 1996.

90. Robbins RJ. Somatostatin and cancer. Metabolism 45(Suppl 1):98$100,1996$.

91. Reubi JC, Schaer JC, Waser B, Mengod G. Expression and localization of somatostatin receptor SSTR1, SSTR2, SSTR3 mRNAs in primary human tumors using in situ hybridization. Cancer Res 54:3455-3459, 1994.
92. Srikant C, Cai J, Shen S. Inhibition of estrogen stimulated growth of MCF-7 human breast cancer cells by octreotide is potentiated by tamoxifen and involves recruitment of PTP1C to the membrane [abstract]. Proc Annual Meeting Endocrine Society, San Francisco, 1996.

93. Pollak M, Costantino J, Polychronakos C, Blauer S, Guyda H, Redmond C, Fisher B, Margolese R. Effect of tamoxifen on serum insulin-like growth factor I levels in stage I breast cancer patients. J Natl Cancer Inst 82:1693-1697, 1990.

94. Pollak M, Ingle JN, Suman VJ, Kugler JW, Nickerson T, Deroo B. Enhancement of tamoxifen-induced suppression of serum IGF-1 levels in metastatic breast cancer patients by coadministration of the somatostatin analog octreotide [abstract]. Proc Annual Meeting American Association for Cancer Research, Washington D.C., 1996.

95. Welsch CW. Host factors affecting the growth of carcinogen-induced rat mammary carcinomas: A review and tribute to Charles Brenton Huggins. Cancer Res 45:3415-3443, 1985.

96. Bakker GH, Setyono-Han B, Foekens JA, Portengen H, van Putten WL, de Jong FH, Lamberts SW, Reubi JC, Klijn JG. The somatostatin analog sandostatin (SMS 201-995) in treatment of DMBAinduced rat mammary tumors. Breast Cancer Res Treat 17:23-32, 1990.

97. Nilsson S, Reubi JC, Kalkner KM, Laissue JA, Horisberger U, Olerud C, Westlin JE. Metastatic hormone-refractory prostatic adenocarcinoma expresses somatostatin receptors and is visualized in vivo by [ ${ }^{111}$ In]-labeled DTPA-D-[Phe $\left.{ }^{1}\right]$-octreotide scintigraphy. Cancer Res 55(Suppl 23):5805s-5810s, 1995.

98. Redding TW, Schally AV, Radulovic S, Milovanovic S, Szepeshazi $\mathrm{K}$, Isaacs JT. Sustained release formulations of luteinizing hormonereleasing hormone antagonist SB-75 inhibit proliferation and enhance apoptotic cell death of human prostate carcinoma (PC-82) in male nude mice. Cancer Res 52:2538-2544, 1992.

99. Gondolez-Barcena D, Vadillo-Buenfil M, Gomez-Orta F, Martinez ME, Fuentes-Garcia M, Cardenas-Cornejo I, Comaru-Schally AM, Schally AV. Treatment of patients with advanced prostatic cancer with LH-RH antagonist SB-75 and of the relapse by the combination of agonist D-Trp ${ }^{6} \mathrm{LH}-\mathrm{RH}$ and somatostatin analog RC-160 [abstract]. Proc Annual Meeting Endocrine Society, New Orleans, 1993.

100. Witzig TE, Letendre L, Gerstner J, Schroeder G, Mailliard JA, Colon-Otero G, Marschke RF, Windschitl HE. Evaluation of a somatostatin analog in the treatment of lymphoproliferative disorders: Results of a phase II North Central Cancer Treatment Group trial. J Clin Oncol 13:2012-5, 1995.

101. Cascinu S, Fedeli A, Fedeli SL, Catalano G. Octreotide versus loperamide in the treatment of fluorouracil-induced diarrhea: a randomized trial. J Clin Oncol 11:148-151, 1993.

102. Szepeshazi K, Lapis K, Schally AV. Effect of combination treatment with analogs of luteinizing hormone releasing hormone (LH-RH) or somatostatin and 5-fluorouracil on pancreatic cancer in hamsters. Int J Cancer 49:260-266, 1991.

103. Radulovic S, Nagy A, Szoke B, Schally AV. Cytotoxic analog of somatostatin containing methotrexate inhibits growth of MIA PaCa-2 human pancreatic cancer xenografts in nude mice. Cancer Lett 62:263-271, 1992.

104. Nagy A, Schally AV, Armatis P, Szepeshazi K, Halmos G, Kovacs M, Zarandi M, Groot K, Miyazaki M, Jungwirth A, Horvath J. Cytotoxic analogs of luteinizing hormone-releasing hormone containing doxorubicin or 2-pyrrolinodoxorubicin, a derivative 500-1000 times more potent. Proc Natl Acad Sci USA 93:7269-7273, 1996.

105. Nagy A, Armatis P, Cai RZ, Szepeshazi K, Halmos G, Schally AV. Design, synthesis, and in vitro evaluation of cytotoxic analogs of bombesin-like peptides containing doxorubicin or its intensly potent derivative, 2-pyrrolinodoxorubicin. Proc Natl Acad Sci USA 94:652656, 1997.

106. Nagy A, Armatis P, Schally AV. High yield conversion of doxorubicin to 2-pyrrolinodoxorubicin, an analog 500-1000 times more potent: Structure-activity relationship of daunosamine-modified derivatives of doxorubicin. Proc Natl Acad Sci USA 93:2464-2469, 1996. 